January 2022

\title{
Female Mentors and Gender Dynamics in Athletic Training
}

Lindsey N. Biggs

Indiana State University, Ibiggs3@sycamores.indstate.edu

Connor A. Burton

Indiana State University, connor.burton@indstate.edu

Lindsey E. Eberman

Indiana State University, lindsey.eberman@indstate.edu

Follow this and additional works at: https://nsuworks.nova.edu/ijahsp

Part of the Rehabilitation and Therapy Commons, and the Sports Sciences Commons

\section{Recommended Citation}

Biggs LN, Burton CA, Eberman LE. Female Mentors and Gender Dynamics in Athletic Training. The Internet Journal of Allied Health Sciences and Practice. 2022 Jan 03;20(1), Article 3.

This Manuscript is brought to you for free and open access by the College of Health Care Sciences at NSUWorks. It has been accepted for inclusion in Internet Journal of Allied Health Sciences and Practice by an authorized editor of NSUWorks. For more information, please contact nsuworks@nova.edu. 


\title{
Female Mentors and Gender Dynamics in Athletic Training
}

\begin{abstract}
Purpose: Female athletic trainers face barriers in accessing female mentors due to the small numbers of same-gender leaders in athletic training. The purpose of this study is to explore the experiences of clinically practicing female athletic trainers with mentorship. Method: Twenty-three (23) athletic trainers who identified as female and had at least 3 years of clinical experience. Interviews occurred using a semistructured interview script. All teleconference interviews were audio-recorded and transcribed verbatim. A 3-person research team analyzed the data and coded it into domains and categories based on the consensual qualitative research process. Credibility was established with multiple researchers, an external auditor, and member checks. Results: Three domains emerged from the data: (1) foundations of mentor relationships, (2) the benefit of mentor relationships, and (3) the influence of female mentors. Participants identified mentor behaviors they value such as not judging, communicating openly and regularly, guiding, challenging, trusting, and supporting. Participants indicated they benefited from their mentor relationships with an evolving friendship, career advancement, administrative support, relationships management, confidence, and empowerment. Participants identified unique influences of female mentors, specifically helping them manage gender-specific challenges and modeling work-life integration. Participants stated an obvious lack of female mentors in athletic training. Conclusions: Findings suggest those that are identified as mentors, regardless of gender, demonstrate foundational behaviors that yield benefits to their mentees. However, the findings also suggest a significant absence of female mentors in athletic training. With the limited number of females in leadership or mentor roles in the field, it is difficult for females to access same-gender mentorship. With this lack of same-gender mentorship, female athletic trainers may face more significant obstacles in managing gender-specific dynamics and challenges in clinical practice.
\end{abstract}

\section{Author Bio(s)}

Lindsey N. Biggs, DAT, LAT, ATC, is an athletic trainer with Community Health Network in Indianapolis, Indiana and is a 2021 graduate of the Indiana State University Doctorate in Athletic Training program.

Connor A. Burton, DAT, LAT, ATC, is an athletic trainer at the Center for Sports Medicine and Performance at Indiana State University and is a 2018 graduate of the Indiana State University Doctorate in Athletic Training program.

Lindsey E. Eberman, Ph.D., LAT, ATC, is the program director and professor for the Indiana State University Doctorate in Athletic Training program.

\section{Acknowledgements}

Acknowledgements We would like to thank Drs. Stephanie Mazerolle Singe and Christianne Eason for serving as external reviewers of our interview script. In addition, we would like to thank Dr. Kenneth Games for serving as an external reviewer and Dr. Matthew Drescher for his mentorship in improving our writing in the final stages of the project. 


\title{
IIJAHSP \\ The Internet Joutnal of Allied Health Sciences and Practice \\ Dedicated to allied health professional practice and education \\ Vol. 20 No. 1 ISSN 1540-580X
}

\section{Female Mentors and Gender Dynamics in Athletic Training}

\author{
Lindsey N. Biggs \\ Connor A. Burton \\ Lindsey E. Eberman \\ Indiana State University \\ United States
}

\begin{abstract}
Purpose: Female athletic trainers face barriers in accessing female mentors due to the small numbers of same-gender leaders in athletic training. The purpose of this study is to explore the experiences of clinically practicing female athletic trainers with mentorship. Method: Twenty-three (23) athletic trainers who identified as female and had at least 3 years of clinical experience. Interviews occurred using a semi-structured interview script. All teleconference interviews were audio-recorded and transcribed verbatim. A 3-person research team analyzed the data and coded it into domains and categories based on the consensual qualitative research process. Credibility was established with multiple researchers, an external auditor, and member checks. Results: Three domains emerged from the data: (1) foundations of mentor relationships, (2) the benefit of mentor relationships, and (3) the influence of female mentors. Participants identified mentor behaviors they value such as not judging, communicating openly and regularly, guiding, challenging, trusting, and supporting. Participants indicated they benefited from their mentor relationships with an evolving friendship, career advancement, administrative support, relationships management, confidence, and empowerment. Participants identified unique influences of female mentors, specifically helping them manage gender-specific challenges and modeling work-life integration. Participants stated an obvious lack of female mentors in athletic training. Conclusions: Findings suggest those that are identified as mentors, regardless of gender, demonstrate foundational behaviors that yield benefits to their mentees. However, the findings also suggest a significant absence of female mentors in athletic training. With the limited number of females in leadership or mentor roles in the field, it is difficult for females to access same-gender mentorship. With this lack of same-gender mentorship, female athletic trainers may face more significant obstacles in managing gender-specific dynamics and challenges in clinical practice.
\end{abstract}

Key Words: Professional development, socialization, transition to practice 


\section{INTRODUCTION}

Mentorship is central to the advancement of anyone in their career. Having a mentor is very important; it allows mentees to gain feedback, advice, and tools to succeed. ${ }^{1}$ In the profession of athletic training it is key for young professionals to have someone they can use as a resource of support and expertise..$^{1}$ In a mentoring relationship, the mentee uses the mentor as a resource for guidance and aids with professional socialization. ${ }^{1,2}$ It is important for mentors to provide a support system for both work and personal matters. ${ }^{1}$ Mentorship can enhance personal and career development, as well as research productivity. ${ }^{2}$ Further, research suggests that the best types of mentorship relationships are when both the mentee and the mentor benefit from the relationship, have effective communication skills, and model respect, honesty, and trust. ${ }^{2}$ Female athletic trainers have found it helpful to receive strong mentorship as an important element to their professional development and learning to reduce or manage workplace discrimination due to gender. ${ }^{2}$ Historically, mentorship occurred naturally within collegiate graduate assistantships and proved to be vital in the development of young professionals.,3 However, in the secondary school setting, mentorship can be more difficult to attain. ${ }^{2}$ Athletic trainers who are the only healthcare provider at their school have a more difficult time getting personal feedback and have to seek out mentorship more purposefully. ${ }^{5}$ With an increasing number of isolated athletic training positions, in addition to the already established, gender-specific barriers, females face greater challenges securing mentorship.., 6

Females face barriers in accessing mentors in many professions due to the small numbers of females in some specialties, especially in the sciences. ${ }^{7}$ For female athletic trainers, two contributors to lack of mentorship are fewer tenured female athletic trainers and limited female leadership in athletic training. Evidence suggests that females are challenged with the demands of the profession more so than their male counterparts, resulting in more females leaving the profession. ${ }^{8}$ Females have reported that a key reason they leave athletic training is due to difficulties of balancing their job and motherhood, and the judgment that comes with balancing their motherhood from co-workers. ${ }^{6}$ According to the National Athletic Trainers' Association salary survey, female athletic trainers make up $69 \%$ of the profession ages $17-35$. However, there is a decrease in the proportion of females to $21 \%$ in athletic trainers ages $36-55$, and even more significantly to $8 \%$ and $2 \%$ respectively for age groups $46-55$ and $56-65 .{ }^{9}$

Beyond female attrition from the field, mentorship is limited by the lack of females in athletic training leadership positions. Females stated they felt discouraged to seek out leadership positions because they haven't seen other females in head athletic trainer roles. ${ }^{6}$ According to the National Athletic Trainers Association, females make up the majority of athletic trainers at $55 \%$, and yet few females hold head athletic trainer positions. ${ }^{7}$ A study surveyed Division I athletic trainers and reported that of 350 institutions, 286 had males (81.71\%) in positions such as Assistant/Associate AD for Sports Medicine, Director of Sports Medicine, or Head Athletic Trainer. ${ }^{10}$ There were 60 leadership positions $(17.14 \%)$ held by females with the remaining four institutions $(1.14 \%)$ having dual positions held by a female and male. ${ }^{10}$ In previous qualitative research, some participants indicated they didn't pursue positions of leadership because of inflexible work-related demands that conflicted with their other life plans. ${ }^{11}$ Gender-role stereotyping and concerns about power negatively affect female athletic trainers. ${ }^{11}$ Barriers like life-balancing and parenting were identified as reasons why females neglect to seek the role of head athletic trainer. 6,11 Some females feel that they are passed over for leadership positions because male administrators believe that their family duties would hinder their ability to perform their jobs at the level required. ${ }^{4}$ Eighty-six percent $(86 \%)$ of female athletic trainers reported conflicts between professional and family responsibilities. ${ }^{6}$ Social barriers also prevent females from gaining the social capital to advance in the profession, including the "good ol' boys club" and the lack of social respect being a female in a male-dominated field.., 11 Attrition and a lack of females in leadership positions highlight the absence of experienced female athletic trainers practicing clinically to provide mentorship for other female athletic trainers.

Ultimately, the lack of female leaders in athletic training means that young professionals have limited mentorship from female athletic trainers in positions of authority, resulting in a void of people that they can look up to and from which to mirror career choices. ${ }^{8}$ With these challenges to finding mentorship, further research is needed to fully understand how female mentors may provide valuable information to mentees, particularly on mitigating gender-specific conflicts within the profession. For mentees, observing females in positions of authority may provide motivation and assurance that younger female athletic trainers can also follow that path. The purpose of this study was to explore the experiences of clinically practicing female athletic trainers with mentorship.

\section{METHODS \\ Design}

This study used a consensual qualitative research (CQR) approach, which has been previously established in athletic training research.12 The CQR tradition was chosen for this project because of the need for robust analysis on females' perception of mentorship in athletic training. Interviewing allowed the participants to narrate their specific experiences with their mentors. The research team consisted of three athletic trainers (AAA, BBB, CCC) who have various levels of experience with the CQR tradition. 


\section{Participants and Setting}

Institutional Review Board approval was obtained through the IRB at Indiana State University before data collection. We used a criterion sampling strategy to recruit female participants for our study. To participate, individuals had to be employed with a clinical position, identified as a female, and have at least 3 years of experience working clinically. As participants responded, interviews were scheduled and conducted by the principal investigator (AAA). It is recommended to obtain 8 to 15 participants to meet data saturation with $\mathrm{CQR} \cdot{ }^{12} \mathrm{~A}$ total of 21 interviews were conducted at which point the research team deemed that data saturation had been achieved. The average age of the participants is $32 \pm 7$ years. Table 1 details the characteristics of the participants.

Table 1. Participant Demographics

\begin{tabular}{|c|c|c|c|c|c|c|}
\hline Pseudonym & Age, $Y$ & $\begin{array}{c}\text { Years of } \\
\text { Certification }\end{array}$ & $\begin{array}{l}\text { Years at } \\
\text { Institution }\end{array}$ & $\begin{array}{l}\text { Female } \\
\text { Mentor(s) }\end{array}$ & $\begin{array}{c}\text { Male } \\
\text { Mentor(s) }\end{array}$ & Job Setting \\
\hline Eva & 25 & 4 & 3 & 2 & 1 & Tactical Medicine \\
\hline Meaghan & 26 & 4 & 1 & 2 & 1 & Clinic \\
\hline Paige & 27 & 6 & 1 & 2 & 1 & Performing Arts \\
\hline Demi & 27 & 5 & 1 & 2 & 0 & Secondary School \\
\hline Francesca & 27 & 5 & 1 & 0 & 2 & College / University \\
\hline Gabby & 28 & 7 & 5 & 3 & 0 & College / University \\
\hline Zara & 28 & 4 & 1 & 2 & 0 & College / University \\
\hline Sophie & 33 & 11 & 9 & 1 & 2 & College / University \\
\hline Shaughna & 34 & 13 & 11 & 2 & 3 & College / University \\
\hline Lucy & 31 & 7 & 7 & 0 & 2 & College / University \\
\hline Dani & 31 & 7 & 7 & 0 & 2 & College / University \\
\hline Rebecca & 31 & 9 & 5 & 1 & 0 & Secondary School \\
\hline Ellie & 31 & 10 & 1 & 3 & 0 & Clinic \\
\hline Rosie & 32 & 7 & 5 & 2 & 2 & College / University \\
\hline Amy & 34 & 12 & 5 & 1 & 2 & $\begin{array}{c}\text { Clinic/ } \\
\text { Professional Sports }\end{array}$ \\
\hline Siannise & 34 & 12 & 4.5 & 1 & 2 & \\
\hline Georgia & 35 & 13 & 12 & 0 & 1 & $\begin{array}{c}\text { Clinic/ } \\
\text { Secondary School }\end{array}$ \\
\hline Joanna & 38 & 17 & 1 & 1 & 0 & Professional Sports \\
\hline Natalia & 40 & 17 & 16 & 1 & 1 & College / University \\
\hline Montana & 44 & 21 & 13 & 1 & 1 & College / University \\
\hline Camilla & 55 & 31 & 15 & 3 & 1 & College / University \\
\hline
\end{tabular}

\section{Instrumentation and Procedures}

The team used the guiding research purpose to develop the semi-structured interview script consisting of 11 questions (Table 2). The interview script was evaluated for content and clarity by three external researchers, all athletic trainers with 10 to 30 years of experience. We used the researchers' feedback to improve the clarity and content of the interview script and to ensure that we addressed our purpose. Before beginning data collection, we conducted practice interviews with two athletic trainers with 4 and 7 years of experience. Minor edits to the interview guide were made to improve the flow of the interview and clarity on the questions' meanings. However, we did not use the data collected during the practice interviews for analysis. 
Table 2. Interview Script

1. Tell me a little bit about yourself relative to your career path and trajectory.

2. You indicated you are eligible for the study because you have been mentored before. Describe what mentoring means to you.

3. Describe the relationship you have with your mentor(s), past and present. If you have or have had more than one, tell me about all of them.

a. How was the relationship established?

i. What factors led you to engage in a mentoring relationship?

ii. What is/was the structure of your relationship? How did you access and engage in the relationship?

b. What are the characteristics of your mentors(s), specifically, years of experience, role/position, and gender?

i. In what ways, if any, do you think gender has influenced your mentorship relationship?

c. Does your mentor hold any type of leadership role?

i. If yes... Describe their leadership role?

d. What qualities, if any, do you think you have gathered or gained from your mentor relationship?

4. Have you experienced any gender-specific challenges in your career? If so, please describe.

a. In what ways, if any, did your mentor(s) adequately prepared you for gender-specific challenges you have experienced?

5. What career assistance, if any, did you experience from that relationship?

a. Please provide examples.

6. What moral/emotional support, if any, did you experience from that relationship?

a. Please provide examples.

7. Are you in a position of authority or influence?

a. If yes... What qualities, if any, do you feel you learned from your mentor that you use in this position?

b. If no... In what ways, if any do you think your relationship with your mentor has prepared you for a position of authority or influence? Why or why not

8. Among your mentoring relationships, which has been your most influential mentor? Why?

9. What do you perceive is the gender makeup of athletic training leadership?

a. Statistics indicate that women hold few leadership positions in athletic training.

i. Why do you think this is so?

ii. How do you think this impacts mentorship?

10. Would you offer mentorship to females? If so, please describe.

11. Is there anything else you want to share about your mentoring experiences?

The semi-structured approach allowed the primary investigator to ask probing questions and gather clarification on responses from the participant. The questions included asking the participant about their relationship with their mentor, characteristics of their mentor, qualities of their mentor, if they feel adequately prepared for gender-specific challenges, and their perception of the gender makeup of athletic training leadership. Female athletic trainers who met the inclusion criteria indicated a willingness to participate and then the primary investigator scheduled the interview via e-mail. Interviews, conducted on Zoom, lasted between 22 to 65 minutes with an average of 38 minutes. All interviews were audio-recorded and transcribed verbatim for data analysis.

\section{Data Analysis, Reflexivity, and Trustworthiness}

After completing the interviews and transcription, each de-identified transcript was sent to the participant for member check accuracy, ensuring all answers were accurately portrayed. Sending each participant their transcript allowed for them to verify their responses and clarify anything that may have misconstrued. The research team then read and examined six transcripts and created a preliminary codebook for analysis. Codes were organized into domains and categories and each member of the team applied the codebook to three previously read transcripts and three new transcripts to confirm the consensus codebook and to ensure that the domains and categories fit the participants' experiences. ${ }^{12}$ The 21 transcripts were then split evenly between the data analysis team, giving each team member seven transcripts to analyze and apply the consensus codebook. The transcripts were then evenly distributed again for an internal audit between the three team members. The primary investigator then completed the cross analysis to ensure the meaningful pieces of data were logically organized and placed into themes. The coded transcripts, codebook, and analyses were then shared with an external reviewer to assess validity. Upon completion of the external review, the categories were counted for frequency calculations. Categories for data analysis were assigned based on frequency and classified as general if identified in 20-21 or more cases, typical if identified in 11-19 cases, variant if identified in 3-10 cases, and rare if identified in 12 case. $^{12}$ 
To account for potential internal bias of the researchers, the team engaged in sharing their potential biases at the onset of the project and throughout the analysis process. The primary investigator, who identifies as female, shared that they have four years of experience as a practicing athletic trainer in the clinical setting and one year of experience in research. The senior researcher, who also identifies as female, shared that they have 17 years of experience as an athletic trainer, 15 years of experience as a researcher, and has engaged in work-life integration and gender-based researcher for all 15 of those years. The other member of the research team, who identifies as male, has 4 years of experience as an athletic trainer, 3 years of experience in research, and serves in a mentorship capacity as part of their clinical duties. In qualitative research, it is expected that the researchers have bias, ${ }^{13}$ particularly when they become embedded in the culture. ${ }^{14}$ Member-checking, multi-analyst triangulation, internal and external auditing, and bias-checking were used to maintain trustworthiness throughout the research process.

\section{RESULTS}

We identified three emergent domains within the data, which are characterized in Figure 1 and Table 3. The three emergent domains included 1) foundations of mentor relationships, 2) benefits of mentor relationships, and 3) influence of female mentorships.

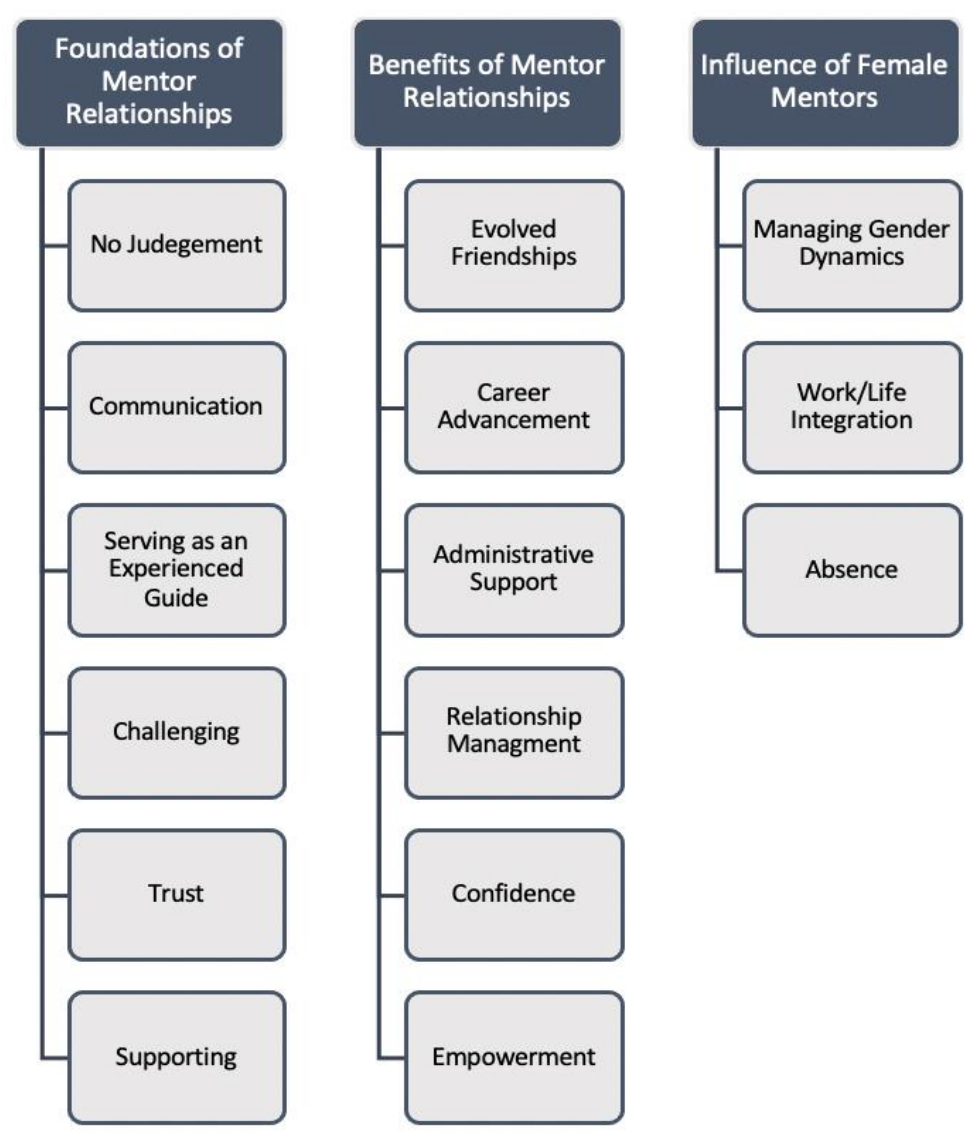

Figure 1. Emerging themes and subthemes from participant interviews related to experiences of clinically practicing females with mentorship. 
Table 3. Frequency of Categories

\begin{tabular}{lcc}
\hline Domain and Category & Counts & Representation Label $^{\text {a }}$ \\
\hline Foundations of Mentor Relationships & & Typical \\
No Judgement & $17 / 21$ & Typical \\
Communication & $18 / 21$ & General \\
Serving as an Experienced Guide & $20 / 21$ & Typical \\
Challenging & $11 / 21$ & Variant \\
Trust & $8 / 21$ & Typical \\
Supporting & $19 / 21$ & \\
Evolved Friendships & & Typical \\
Career Advancement & $18 / 21$ & General \\
Administrative Support & $20 / 21$ & Variant \\
Relationship Management & $8 / 21$ & Typical \\
Confidence & $15 / 21$ & Typical \\
Empowerment & $16 / 21$ & Variant \\
Influence of Female Mentors & $9 / 21$ & \\
Managing Gender Dynamics & & General \\
Work-Life Integration & $20 / 21$ & Variant \\
Absence & $8 / 21$ & Typical \\
\hline
\end{tabular}

aQuotes are labeled based on the representation of the category among the participant transcripts. General $=20-21$ participants; Typical $=11-19$ participants; Variant $=3-10$ participants; Rare $=1-2$ participants .

Within the foundations of mentor relationships domain, athletic trainers described the qualities and characteristics that were the base of their mentor relationships. Six categories emerged: no judgment, communication, serving as an experienced guide, challenging, trust, and supporting. Participants specifically discussed mentors not placing judgment on them in their clinical experience or their educational journey. Participants voiced the importance of having communication with their mentor, specifically having an open dialog, having conversations about their mentors' experiences, and the freedom to openly ask them questions. Participants valued keeping in touch with their mentor through e-mail, calling, and seeing each other at conventions. Participants generally appreciated having a mentor that guided them through certain obstacles and provided an example of how to navigate situations. It was noted that the participants liked to be challenged by their mentors; they viewed it made them better athletic trainers. It was also stated that they greatly valued trust and support within their mentorship relationship, they liked having a sounding board that they could go to. Supporting quotes for the foundations of mentor relationships domain can be found in Table 4. 
Table 4. Participant Demographics

\begin{tabular}{|c|c|}
\hline Category & Supporting Quote \\
\hline \multirow{3}{*}{ 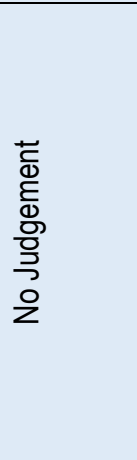 } & $\begin{array}{l}\text { My mentor created a bond with me because of how he let me be a student. It really just allowed me to ask him } \\
\text { anything, even what I felt were stupid questions. Because of that, we have still just been really open with each } \\
\text { other about needing help with things or wanting another opinion. He's even called me with questions about } \\
\text { specific techniques that he knows I have more knowledge on. So, to me, it's interesting to see how that } \\
\text { relationship has grown as I gain more experience. -Francesca }\end{array}$ \\
\hline & $\begin{array}{l}\text { My mentor also taught class at one point. And she established the relationship that if you had questions, you } \\
\text { could go to her with questions. Regardless of what the questions were. -Siannise }\end{array}$ \\
\hline & $\begin{array}{l}\text { My mentors said "if you need anything, come talk to me". And I actually took that extra step to do it. I was } \\
\text { persistent in it and not too proud to say I was struggling or that I had a question with something, because I felt } \\
\text { like in those moments [my mentors] were able to help me a lot more than if I went in thinking I knew everything. } \\
\text {-Rosie }\end{array}$ \\
\hline \multirow{3}{*}{ 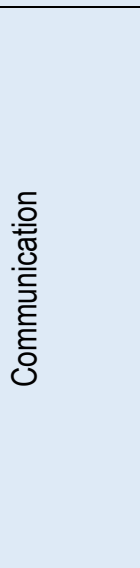 } & $\begin{array}{l}\text { I think that most of my relationships, when it comes to mentoring, have really been kind of more of just an open } \\
\text { dialogue. Not necessarily teaching, or telling me how to do this, telling me how to be better, but just the } \\
\text { opportunity for an open dialogue to hear about their history and their experiences and to share my experiences. } \\
\text { And then to ask questions that come about as part of our day to day activities. I don't think that that there was } \\
\text { any "okay let's sit down and work together, I'm going to guide you," I really think that it was more of an open } \\
\text { dialogue. -Camilla }\end{array}$ \\
\hline & $\begin{array}{l}\text { After graduation it's been awesome to still be in touch with them. And it may not be as frequently as I would like. } \\
\text { But, I see them at conventions, and just other e-mail communications still keeping in touch. They're all great } \\
\text { resources to fall back on when you have those crazy scenarios or questions or just good people to always have } \\
\text { in your back pocket. -Sophie }\end{array}$ \\
\hline & $\begin{array}{l}\text { The head athletic trainer that I had as part of my undergrad experience, she did a really good job at just building } \\
\text { relationship with the students that she was working with. I went to a private Christian institution for undergrad } \\
\text { and she had a Bible study with a couple of us, specifically our senior year. We were able to talk about things, } \\
\text { about our faith, about how that integrated with our profession. -Joanna }\end{array}$ \\
\hline \multirow{4}{*}{ 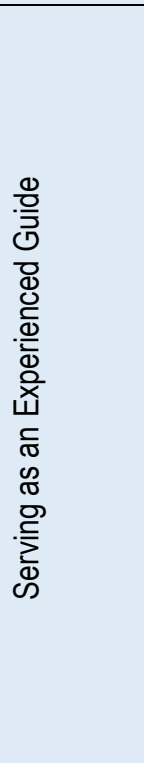 } & $\begin{array}{l}\text { My mentor is an athletic trainer at a local community college. She taught in our program for a long period of time. } \\
\text { And she probably, right now, provides the most guidance for me because she is someone who has a breadth of } \\
\text { experience. She knows how I think and how I work. And so when I have something that I'm struggling with she } \\
\text { is usually the first person that I communicate with, I can say "I'm having this issue, what are your thoughts and } \\
\text { we can talk through it." -Camilla }\end{array}$ \\
\hline & $\begin{array}{l}\text { Guidance is the biggest one thing I got from my mentors. I know in undergrad it's really hard, you have your } \\
\text { athletic training classes, your regular classes, I had a job, then you have clinical hours. So just having that } \\
\text { guidance of what would be best. I look back at when I was a senior in undergrad and having that guidance there, } \\
\text { I don't know how I would have made it. I probably would have not moved to where I am now. It is the guidance } \\
\text { to make sure I do what's best for myself professionally and personally. -Gabby }\end{array}$ \\
\hline & $\begin{array}{l}\text { For me, mentoring is having someone kind of just take you under their wing and just show you the ropes. Whether } \\
\text { that be as an athletic trainer as a person, whether that's with your athletic training skills or in your job setting. But } \\
\text { having someone take you under their wing and teaching you kind of how that particular company works, or how } \\
\text { that particular setting works and just helping you through your trials and tribulations. -Rebecca }\end{array}$ \\
\hline & $\begin{array}{l}\text { A big factor that led me into a mentoring relationship was being young and confused. I was just looking for } \\
\text { someone to kind of show me the ropes and help me through and speak to me kind of on my level. Where some } \\
\text { of the other teachers were very much teachers, and they only spoke to you at the teacher level, and they couldn't } \\
\text { relate to everybody, but my mentor was very good about meeting me the on the level I was at and helping me } \\
\text { through that way. -Siannise }\end{array}$ \\
\hline
\end{tabular}




\begin{tabular}{|c|c|}
\hline \multirow{3}{*}{ 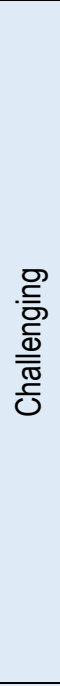 } & $\begin{array}{l}\text { My mentor, at the time, felt very difficult to work with. But looking back on it, he was only doing it because he } \\
\text { cared about us as students. So, he would ask us to do things that we didn't feel comfortable doing, like it was all } \\
\text { within what we should be doing, but challenging us to make decisions. Asking us to be creative and } \\
\text { brainstorming, making us step outside of our comfort zone. Looking back on that, I'm now realizing how much } \\
\text { that helped me prepare for the world of athletic training. We weren't just standing there watching or taping, he } \\
\text { really challenged us. -Sophie }\end{array}$ \\
\hline & $\begin{array}{l}\text { I've always kind of wanted to be best in whatever I do, I strive to be like top upper level. I want to be a go-to } \\
\text { person, I want to be someone that people can rely on and trust on or like, "she does a good job". I wanted that } \\
\text { and I could see that [my mentors] were that. So, I wanted to pick their brains, figure out how they got there, or } \\
\text { figure out what they thought I was missing and needed to work on to better myself. Sometimes self-introspection } \\
\text { can be hard, it's not one of my strengths, so it's easier to hear it from someone else. Then be able to work towards } \\
\text { it and see it and kind of realize it and then move forward. So, I kind of just rely on them for input and feedback. - } \\
\text { Zara }\end{array}$ \\
\hline & $\begin{array}{l}\text { My mentor was pretty hands off. I was forced, to a certain extent, to learn and grow, knowing that I wasn't going } \\
\text { to be coddled, but at the same time he wasn't going to let me use something outside my scope, or not be a } \\
\text { resource if I get stuck. If I was stuck on something, he would want to know what research articles I didn't } \\
\text { understand. He always forced me to be prepared. -Paige }\end{array}$ \\
\hline \multirow{3}{*}{ 离 } & $\begin{array}{l}\text { My mentor really fostered my learning. I felt like he let me do more as a student than he would let other individuals } \\
\text { do, and I think what resonated with me so much as a student, he described being a preceptor as providing a } \\
\text { safety net. Which to him meant, you might fall. You might not make it across the balance beam successfully. But } \\
\text { you're not going to hit the floor. So, he let me make mistakes and learn from those mistakes and because he } \\
\text { would be open and honest with me about that, it made it way easier for me to be. -Francesca }\end{array}$ \\
\hline & $\begin{array}{l}\text { I've had doctors before when, you go to either a doctor's visit or you're consulting with them about mutual patients, } \\
\text { they can make you feel like you don't know anything, just in two sentences. Never once has my mentor ever } \\
\text { made me feel that way. And I feel like she values the information she has. And she always says, "you guys see } \\
\text { the mechanism of injury, you guys know the athletes, you know their pain tolerance, I order the imaging and help } \\
\text { treat, you know more than I do. So, if you tell me you think it's a torn ACL and I don't get a good read on a } \\
\text { Lachmans } 24 \text { hours later, the way you do, I'm believing you before I believe in what I'm feeling because I know } \\
\text { you", which is huge. -Shaughna }\end{array}$ \\
\hline & $\begin{array}{l}\text { I think I learned how to have a lot of respect and forced trust with someone else in that position. It was trusting } \\
\text { someone to get done what they say they're going to get done. So that's really scary to have no control over those } \\
\text { things. And for my mentor, to be able to delegate really important, potentially contract breaking tasks, to a young } \\
\text { clinician was big. He had worked on this contract for such a long time, but he had a full-time job. So he needed } \\
\text { to trust that I was going to get it done. So it was a learning curve for both of us. -Eva }\end{array}$ \\
\hline \multirow{3}{*}{$\begin{array}{l}\frac{t}{\circ} \\
\frac{0}{2} \\
\text { के }\end{array}$} & $\begin{array}{l}\text { I knew that I could go to my mentor with any kind of questions or anything about life in general. He was a great } \\
\text { support system. When I was four or five hours away from my family, he kind of took me in as his own child. - } \\
\text { Georgia }\end{array}$ \\
\hline & $\begin{array}{l}\text { I think that's probably most support l've gotten from my mentors, the emotional and the moral support. That to } \\
\text { me is more valuable than anything. I can look up online how to develop a mental health policy. It's more about } \\
\text { the challenges we face day to day, getting policy through legal and risk management and all the frustrations that } \\
\text { go along with it. It's not about dotting i's and crossing t's. It really is more about having someone to kind of go } \\
\text { back and forth with and share frustrations and challenges and successes and the things that are good and bad. } \\
\text { So I think it's far more on the emotional side than it is anything black and white. -Camilla }\end{array}$ \\
\hline & $\begin{array}{l}\text { My mentor and I had a lot of vent sessions about everything I've had to deal with, which he has helped either } \\
\text { give me support or help me with trying to come up with some sort of help. Then also, just being a sounding board. } \\
\text { It's nice to have a sounding board who actually knows what I'm talking about when I'm talking about these things. } \\
\text { Whether or not they give me advice or not, it's just nice to have someone who I can talk to that can understand } \\
\text { what I'm going through. I've actually done that with both of my mentors when l've been extra stressed. I just go } \\
\text { and spill my guts about everything that's happened in the last however long, just to get it out of my system. -Lucy }\end{array}$ \\
\hline
\end{tabular}

The benefits of mentor relationship domain included positive outcomes the participants experienced directly from their mentorship relationship. Participants told stories about how their mentors have assisted with their career advancement, ranging from being references, using their network, to providing jobs for their mentees. The majority of mentor relationships evolved into friendships, and participants felt that added another aspect to their professional relationship. Mentors provided support and guidance with 
administrative challenges and relationship management. This includes advising on how to communicate and interact with coaches, direction on how to write policies and procedures, and how to avoid legal challenges. Confidence grew within the participants, especially when they were transitioning to practice, because of these mentor relationships. Mentees felt their mentors taught them how to advocate for themselves and for what they believe in. Supporting quotes for the benefits of mentor relationships domain can be found in Table 5.

Table 5. Supporting Quotes for the Benefits of Mentor Relationships Domain and Categories

\begin{tabular}{|c|c|}
\hline Category & Support Quotes \\
\hline \multirow{3}{*}{ 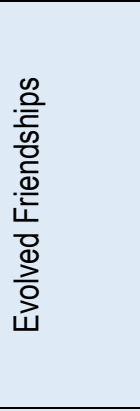 } & $\begin{array}{l}\text { I think a mentor is somebody that's been in the profession, that you kind of just bond with. I don't know exactly } \\
\text { why that bond happens, we just all have our person, it's one of those things. But I think it's more they type of } \\
\text { person and the aspect of you could always count on to pick up their phone, that you know that no matter how } \\
\text { much time has passed that they will always at least answer the phone. -Paige }\end{array}$ \\
\hline & $\begin{array}{l}\text { There's more than just the professional work relationship. There's also, you know, the friendship aspect. I mean } \\
\text { my mentor crocheted my son a baby blanket, like we're close, we're good friends on top of it all. -Demi }\end{array}$ \\
\hline & $\begin{array}{l}\text { Both of my mentors started as working relationships and then turned into friendships. I would see them regularly } \\
\text { at work or we would go hang out outside of work. My one mentor relationship really turned more into a friendship. } \\
\text { She had twin boys when I was there, and I would go to her house and help her out in the evenings with the boys } \\
\text { while her husband was at work. And then it kind of just morphed as a friendship and a mentorship. -Zara }\end{array}$ \\
\hline \multirow{3}{*}{ 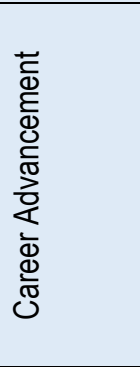 } & $\begin{array}{l}\text { She has been very instrumental in helping me more think through career advancement and to be a sounding } \\
\text { board. She's had good connections within the collegiate ranks, where I started off, and was able to kind of vouch } \\
\text { for me and be kind of that advocate for me on the sidelines and I think that's been great. -Amy }\end{array}$ \\
\hline & $\begin{array}{l}\text { I think relationships are everything and how you get where you get in athletics. My mentor was who I built a } \\
\text { relationship with, who I got my graduate assistantship with, and then you know, essentially continued to be a } \\
\text { reference for me in the future possessions. So yeah, she got my foot in the door. -Joanna }\end{array}$ \\
\hline & $\begin{array}{l}\text { My mentor and I talk a decent amount and she's definitely helped me navigate my different career choices. I } \\
\text { have bounced around settings still in a young career and she would talk me through those choices. She gave } \\
\text { me input because she did some career changes too. So that's been really nice. -Meaghan }\end{array}$ \\
\hline \multirow{3}{*}{ 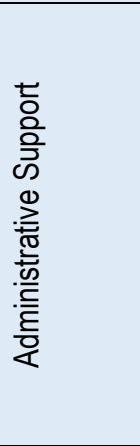 } & $\begin{array}{l}\text { The third mentor I have is not an athletic trainer, he was the clinical manager in the clinic that I'm at, he recently } \\
\text { left, but I've continued that relationship. But he's really mentored me in more the administrative type of goal that } \\
\text { I want. I've been working on kind of stepping into that administrative role. -Amy }\end{array}$ \\
\hline & $\begin{array}{l}\text { I have a mentor for whenever I'm trying to write a policy, or if I'm trying to read or write pretty much anything, I } \\
\text { looked at her for guidance. She would help me make it sound as professional as possible and make sure that } \\
\text { I'm covering all my bases. -Natalia }\end{array}$ \\
\hline & $\begin{array}{l}\text { My mentor is a big proponent of malpractice suits and how to avoid those, policy and procedures and having } \\
\text { everything locked in place and having everything in order. He's spoke professionally many times about that. } \\
\text { Sometimes as athletic trainers, we don't think about all that. Like, what could go wrong and how do we handle } \\
\text { that. So kind of being prepared in that aspect brought a new light to how we as a department update our policies } \\
\text { and procedures and have everything in place there. -Dani }\end{array}$ \\
\hline \multirow{2}{*}{ 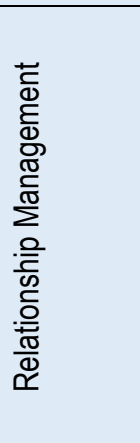 } & $\begin{array}{l}\text { I think my mentor really focused probably more on all the other things of athletic training. Being in the real world } \\
\text { and all the things that you just don't learn in school. They helped with all the interpersonal aspects of athletic } \\
\text { training. Communicating with coaches, navigating difficult and uncomfortable situations, dealing with difficult } \\
\text { student athletes. You know, we go through so much athletic training education and it helps prepare you to be } \\
\text { working. But, there's so many challenges that pop up that you're not really sure how to deal with. So [my mentor] } \\
\text { was really great at helping you know navigate those. -Sophie }\end{array}$ \\
\hline & $\begin{array}{l}\text { Something that has helped is just seeing a good boss. And when I say that, my mentor is level headed and } \\
\text { grounded. I think one of the things that he taught me is you really never know what somebody else is going } \\
\text { through on a daily basis. And if you know, someone comes in and they're having a bad day and they just seem } \\
\text { off, there might be a reason that they're off. So just being understanding that everyone is approaching a situation } \\
\text { a little bit differently. -Montana }\end{array}$ \\
\hline
\end{tabular}




\begin{tabular}{|c|c|}
\hline & $\begin{array}{l}\text { My mentor taught me how to kind of balance things better and about relationships and how important they are } \\
\text { to build within your department and with your teams because it's really the people that makes the place, and I've } \\
\text { noticed that with them. They all taught me different aspects and different ways to handle different personalities } \\
\text { and stuff like that. And I think that something l've really taken with me. -Rosie }\end{array}$ \\
\hline \multirow{4}{*}{ 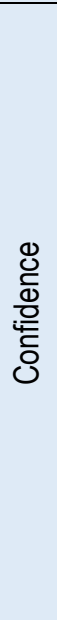 } & $\begin{array}{l}\text { Once you have confidence then I feel like it makes it a little easier to sleep at night, not questioning everything } \\
\text { you do. Especially in the beginning, I feel like I questioned everything I did. So I think the biggest thing that both } \\
\text { [of my mentors] gave me is just confidence. -Lucy }\end{array}$ \\
\hline & $\begin{array}{l}\text { My mentor taught me to just not second guessing myself so much and trying to really display confidence, thinking } \\
\text { about things from multiple different views. So not just my gut reaction but trying to think about situations from } \\
\text { multiple different views, being unbiased, being thoughtful, you know, to all people involved not just yourself. - } \\
\text { Sophie }\end{array}$ \\
\hline & $\begin{array}{l}\text { I think my mentor definitely taught me patience and communication. Just being kind of new to the field and } \\
\text { everything is nerve wracking when you first start. I think having that patience with them and being able to } \\
\text { communicate helps them feel more comfortable and more apt to ask questions and understand why you're doing } \\
\text { what you're doing, instead of you know, like, this is the way I do it, and this is why I do it, and that's it. So I think } \\
\text { having that fluid communication of why we're doing it for specific reasons, help them kind of grow as individuals. } \\
\text {-Dani }\end{array}$ \\
\hline & $\begin{array}{l}\text { My mentor that I had in grad school just taught me to be confident in myself and know that whatever the situation } \\
\text { that I was in, I was strong enough for it. -Gabby }\end{array}$ \\
\hline \multirow{3}{*}{ 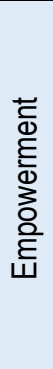 } & $\begin{array}{l}\text { All three of my mentors taught me to stand my ground. To always be willing to listen to how many other } \\
\text { perspectives there are, but if there's something that you truly feel passionate about, do your research to defend } \\
\text { what you have to say or defend how you feel. Also, if there is something that you feel is true and right and just } \\
\text { and someone's just not having it, that's not the hill you have to die on. -Eva }\end{array}$ \\
\hline & $\begin{array}{l}\text { That's one of the things that [my mentor has] probably helped me with the most is how do you advocate for } \\
\text { yourself. And that's not really something that we're taught to do very well. So that's probably been the most } \\
\text { beneficial part about that mentorship. -Montana }\end{array}$ \\
\hline & $\begin{array}{l}\text { [My mentor] is one of the best sports medicine physicians I've ever worked for. Like she is phenomenal. And I've } \\
\text { never been treated like an equal by a doctor and she does that, which just is so empowering. -Shaughna }\end{array}$ \\
\hline
\end{tabular}

The influence of the female mentorship domain revealed participants felt impacted by female mentorship or the lack thereof. Participants shared stories about gender dynamics that were managed through help from their female mentors. A large barrier that females face in the field is work-life integration, especially when transitioning into the time of their life when they start a family. It was important to see their mentors display understanding and support towards work-life integration. Generally, the participants wished that they would have had guidance on how to gain trust from coaches/patients and how to assert themselves in a male dominated field. Many of the women stated that they want to see someone like them, a female working clinically, that also has a family. Supporting quotes for the influence of female mentorship domain can be found in Table 6 .

Table 6. Supporting Quotes for the Influence of Female Mentorship Domain and Categories

\begin{tabular}{|c|c|}
\hline Category & Supporting Quote \\
\hline \multirow{3}{*}{ 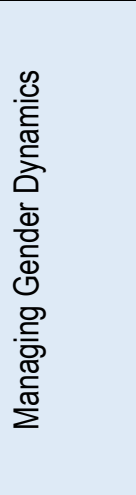 } & $\begin{array}{l}\text { My mentor was incredibly helpful because one of the hardest things about breaking into tactical medicine as a } \\
\text { young female is the female part, and she knew that. She experienced the exact same thing, there are men who } \\
\text { genuinely believe women do not belong anywhere around or near the fire service. And she experienced that } \\
\text { firsthand, so it was very helpful for me that she was a female. -Eva }\end{array}$ \\
\hline & $\begin{array}{l}\text { I was working in like a very male dominated sport, so it was really hard to like gain coaches trust or like assert } \\
\text { myself. I struggled a lot with that. And actually, that's when I debated leaving the profession and going back to } \\
\text { school for something else. It wasn't until I was able to reach out to my mentors again and kind of talk through that. } \\
\text { They helped me revisit the idea of there are different settings I can do, different sports to work or things like that, } \\
\text { I was able to work through that. -Meaghan }\end{array}$ \\
\hline & $\begin{array}{l}\text { I think I admire the females more, especially if they work with male sports, because I feel like that's still a stigma } \\
\text { that females are trying to break. We've had a lot of strides, and it's gotten a lot better. But I think for me, that was } \\
\text { a draw to my mentor, because I was like "okay she's a female like me and she did it, so why can't I?" -Rosie }\end{array}$ \\
\hline
\end{tabular}




\begin{tabular}{|c|c|}
\hline \multirow{3}{*}{ 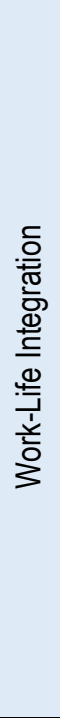 } & $\begin{array}{l}\text { I find most of my newer levels of mentorship are coming from Facebook mommy groups that are specifically } \\
\text { athletic training minded. Professionally, a huge network, there are women in all different avenues, and everyone } \\
\text { shares their stories about past experiences. That's been more beneficial to me now as an adult athletic trainer } \\
\text { than any previous mentorship has. The previous mentorship has laid the groundwork, but this current network is } \\
\text { what fuels me forward, keeps me grounded, and makes me appreciate my profession. There's a lot of us with a } \\
\text { similar mindset and similar circumstances and by sharing those experiences, it really helps keep us motivated. So } \\
\text { it's a good group. I've gotten a lot out of it, personally and professionally. -Siannise }\end{array}$ \\
\hline & $\begin{array}{l}\text { This mentor understood the family aspect of my life, but my other mentors, none of them had family. When I was } \\
\text { in grad school, he wasn't married, he had no kids. My undergrad director had a wife, but no family. So the aspect } \\
\text { and understanding that my mentor had, she understood that when you get home from work, there's more work to } \\
\text { be done. Regardless of gender, I'm not saying that my male mentors didn't. But I think it's mostly because they } \\
\text { didn't have families, more so than maybe gender? My female mentor's relatability to work life balance, I've never } \\
\text { had someone advocate for work life balance more than my two female mentors ever, ever. They would say, "you } \\
\text { need to spend time at home, we'll get this done later and don't worry about this project," which brings you closer } \\
\text { because there's an understanding that you have a life outside of work. -Shaughna }\end{array}$ \\
\hline & $\begin{array}{l}\text { My mentor would show his family life and the balance between work and family. He would bring his kids to practice, } \\
\text { bring his kids to work and let his kids see what he does and then still being really present in their lives. And then } \\
\text { he's just a guy that you can sit down in the office and have whatever conversation you want with him. -Georgia }\end{array}$ \\
\hline \multirow{4}{*}{ 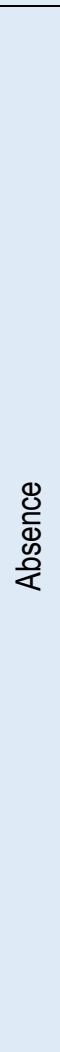 } & $\begin{array}{l}\text { I don't know that I've necessarily gotten the kind of mentorship of how to function as a woman in athletic training. } \\
\text { Just because I haven't seen someone like me. All of the women that I know, that are athletic trainers in a collegiate } \\
\text { setting either are not married or as soon as they have kids, they leave the collegiate setting. So, I think that's part } \\
\text { of the reason why I interact the way that I do with the athletic training students. I didn't feel like I saw someone like } \\
\text { me or what I wanted my path to be when I was a student, so I want to be that for them. So I feel like not having a } \\
\text { woman as a mentor in my current setting limits not only work life balance, but just functioning as a woman in the } \\
\text { profession. -Francesca }\end{array}$ \\
\hline & $\begin{array}{l}\text { I think the lack of women in leadership positions greatly affects mentorship. I think if you don't have mentors who } \\
\text { are in the field long enough, you're not going to have a female mentor to look up to. I think one of the biggest } \\
\text { drawbacks, is that we don't have enough females established in their career long term in order to mentor other } \\
\text { females who are coming up. I wish I had a female mentor who would have said to me, "at this point in your life, } \\
\text { you're going to experience this, then when your life transitions over to this milestone, you're going to experience } \\
\text { this and that". I think not having enough females who have advanced their career within the clinical field is a huge } \\
\text { drawback or a huge downside. -Montana }\end{array}$ \\
\hline & $\begin{array}{l}\text { I think it makes it all that more important for the females who are in that position to be good mentors, to be someone } \\
\text { that young athletic trainers, female athletic trainers especially, can look up to. I think it can sometimes be } \\
\text { discouraging for young female athletic trainers, when they don't see someone up there in those positions. It's kind } \\
\text { of like, "well, no one is there, am I ever going to be able to do that." But I think seeing the women who have made } \\
\text { it, make them all that much more inspiring because they are the minority. Thinking "she did that, I can do that too." } \\
\text {-Rebecca }\end{array}$ \\
\hline & $\begin{array}{l}\text { I think that ultimately, the lack of women in leadership positions has a pretty profound impact on mentorship. I } \\
\text { think it's important to see someone to aspire to be, someone that you can see in real life. If I go back to when Julie } \\
\text { Max was the president of the National Athletic Trainers Association you say, "wow, I want to be like her, look what } \\
\text { she did. She was a head athletic trainer at a Division I institution, she was a teacher, she was a preceptor, she's } \\
\text { the president of the NATA, I could be like her." I think seeing that as a young professional is really important. - } \\
\text { Camilla }\end{array}$ \\
\hline
\end{tabular}

\section{DISCUSSION}

Though there has been previous research on mentorship and females within athletic training, there is still a lack of research on how same-gender mentorships may differently impact career outcomes. Mentors, regardless of gender, demonstrate foundational behaviors that yield multiple benefits to their mentees. We confirmed previous findings that there are many benefits to having mentorship in athletic training. ${ }^{1,2}$ However, there is a significant lack of experienced female athletic trainers that can be mentors, specifically to help other female athletic trainers mitigate gender-specific challenges and demonstrate successful work-life integration. Though we could confirm previous findings, this study differs from prior studies in that we focused on female mentors in athletic training instead of the female athletic trainer experience or athletic trainer experience with mentors. Females make up the largest proportion of athletic trainers between ages 22 and 28 years, but their presence in the profession drastically declines between ages 28 and 35 years. ${ }^{15}$ The decrease in female athletic trainers as years of work experience increase, challenges 
opportunities for females in the profession to have same-gender mentorship and learn to mitigate gender-specific challenges. In short, there is a lack of females teaching females how to navigate a male dominated field across all career stages.

\section{Foundations of Mentor Relationships}

Females having a mentor to serve as an experienced guide was noted with great importance. It is beneficial to have someone to show a mentee how to navigate their specific workplace and how to integrate into a new environment. Mentees tend to emulate the behaviors of their previous mentors, specifically, collegiate preceptors often model behaviors of other preceptors working in the same setting. ${ }^{1}$ Effective mentorship relationships are developed upon support, communication, commitment, and trust. 1,2,16-18 Mentees want emotional and moral support from their mentors, especially in situations where they were far from home, in a new position, or facing stressful times. ${ }^{19}$

There are many different forms of communication between mentor and mentee, depending on if they are located in the same place. Interviewees voiced this wide array, explaining how they would meet with their mentor in person, communicate with phone calls, texts, and e-mails, and see their mentors at conferences. When mentees feel that they have effective communication with their mentor, it leads to effective interpersonal relationships and aids in their willingness to commit to mentorship. ${ }^{1}$ Participants noted how important it was that their mentor showed no judgment within their relationships and they appreciated when their mentors pushed them in situations they felt were out of their comfort zone, forcing them to grow and learn. They appreciated that their mentors made them feel that they could go to them with any question and that they could be open with one another. These relationships are strongest when mentees trust their mentors and vice versa. When mentors trust mentees with specific tasks or aspects of their job, it encourages mutual trust back. Alongside having trust, mentees need a balance of support and challenge from their mentors. ${ }^{18}$ Mentorships are built on the basis of trust, support, and serving as an experiential guide. $1,2,16,18$

\section{Benefits of Mentor Relationships}

Participants described the special importance that came from an evolving friendship with their mentors. Having more than a professional relationship helped foster the mentorship and make it mutually beneficial for both mentee and mentor. 18,19 When the relationship is built on more than just professional standards, there is a special bond that can aid in mentees receiving more advancement in their careers. ${ }^{17,19}$ Participants in this study, as well as in previous research, felt that their supervisors cared for them on a personal level and created friendships.3,19 Mentors challenge and coach mentees in gaining new knowledge and developing new skills. ${ }^{19}$ Career advancement ranges from receiving help building resumes to being recommended or hired for positions. Having mentors who are established in their careers is a benefit, not only from a networking standpoint, but also in terms of advising the mentee on what they could do moving forward in their career. Mentors must instill confidence in mentees, most critically at the beginning of their practice. ${ }^{17-20}$ When transitioning into practice, young professionals can second guess themselves. However, when mentors gave encouragement and offered support for the participants' decisions, participants felt as though their confidence grew. In the nursing literature, mentors were critical in building confidence and preparing to practice independently. ${ }^{21}$ Mentors provided someone to look up to as a good boss or a model for good leadership, therefore giving mentees guidance on positive relationship management.

Participants described feeling empowered by their mentors. Poor mentorship can lead to disempowerment, job dissatisfaction, and burnout. ${ }^{16}$ Participants explained that their mentors taught them how to stand their ground, stand up for themselves in difficult situations and advocate for themselves throughout their careers. Mentoring programs are used to support role transition, empower and retrain new faculty and build female mentoring capacity. ${ }^{16}$ For our participants, seeing other powerful females or those in leadership positions made them feel empowered themselves. Additional research should further explore the role of empowerment in same and mixed-gender mentor relationships.

\section{Influence of Female Mentors}

With the limited number of females in leadership or mentor roles in the field, it is difficult for females to access same-gender mentorship. With this lack of same-gender mentorship, female athletic trainers may face more significant obstacles in managing gender-specific dynamics and challenges in clinical practice. Numerous participants spoke about challenges based on being a female in the athletic training field. These experiences included breaking the stigma of working with male sports, being the only female at the table, being assertive with male coaches, and dealing with sexual harassment and assault in the workplace.

Historically, there have been positions denied to females based on not wanting to have a female in the all-male locker room. In 2019, the National Football League's Bengals hired their first female student intern. They stated that this was their first female hire "because their facilities were never designed for coed athletic trainers." 22 Females working in sports industries are challenged as a whole, not only with the salary gap but in experiencing unfair treatment and discrimination in an unfriendly male-dominated work environment. ${ }^{23}$ Female mentors provide guidance on navigating these specific challenges. Participants noted how their mentors 
explain how they previously dealt with these challenges and give guidance on how to move forward. It is easier for mentees to handle gender-specific challenges after learning from someone else doing it first. ${ }^{24}$

Lack of racial/ethnic and gender concordance has also been perceived as an obstacle for minority mentees. ${ }^{25}$ Specifically, Black, female athletic trainers believe they would benefit more from having a female as a mentor as they stated they are uncomfortable seeking mentorship from males ${ }^{26}$ Having female mentors in athletic training could increase the chance of minority mentees seeking out positive mentorship opportunities. ${ }^{25}$ It was recommended to athletic training educators to offer protection against the persistent barriers of sexism, racism, and classism that threaten the academic and professional success of the Black female athletic training students, one of those protections being the addition of mentors. ${ }^{26}$

Literature shows that many females leave the profession or the clinical setting when they start to have families. According to the National Athletic Training Association's position statement on Facilitating Work-Life Balance in Athletic Training Practice Settings, gender has been linked to work-life conflict in other professions as well as in athletic training. ${ }^{27}$ Some female students have even voiced worries about having a family in their future and balancing their work. ${ }^{28}$ Motherhood and balancing the role of motherhood with work were perceived as challenges, but the presence of support networks was common in helping with this challenge. ${ }^{29}$ Strategies to achieve work-life balance included seeing their preceptor achieve work-life balance and being able to model it for others. ${ }^{28}$ There is a desire, especially in the Division I setting, for female role models who are able to model an adequate amount of work-life balance. ${ }^{30}$ Seeking work-life balance has been seen as a great barrier in the athletic training field and establishing structures and cultures that embrace balance needs to be a greater priority. ${ }^{27}$ Future research should focus on how to retain females in the profession, especially with the struggle of work-life integration when females try to have families.

We acknowledge that our participants had multiple mentors of both genders and that these mentors and relationships were extremely beneficial. However, the participants who did not express having female mentorship also said they would have benefited from female mentorship. There is a lack of experienced females in the field and ultimately the lack of females in leadership positions affects mentorship. Literature highlights how, as females advance their careers, they have fewer female mentors to access for guidance, which can lead females to believe that "being a female limits advancement." ${ }^{1}$ Exposure to successful female role models, especially in Science, Technology, Engineering and Math fields, is important for females to see that they can succeed in their career while having a personal life. ${ }^{32}$ The glass ceiling has been seen as a barrier for females trying to advance their careers and having female role models who have successfully broken the glass ceiling is important to visualize. ${ }^{32,33}$ Females need to have someone to look up to, have someone to aspire to be, have someone in leadership roles so that they can envision themselves in leadership roles as well. ${ }^{31}$ Females want guidance through gender-specific challenges that females face, and many participants voiced they never received that guidance. The status quo in the athletic training field leads to a cyclical pattern: females are not in leadership positions, which leads to females not knowing how to navigate gender-specific challenges, therefore they do not seek out or are not promoted to leadership positions. While there is a lack of literature to illustrate all of the benefits of female samegender mentorship, current data show that it's important for females to have female mentors in athletic training.

\section{Recommendations}

Those in leadership positions should focus on promoting female athletic trainers into positions that allow them to successfully mentor other females, role model work-life integration, and encourage persistence in the profession. In emergency medicine, a mentorship program with eight key guidelines has been effective at fostering more females in the specialty. ${ }^{17}$ Providing mentors and role models for inspiration and guidance, offering career advice and support in establishing goals and recognizing opportunities were part of the guidelines. ${ }^{18}$ In addition, the guidelines promote work-life balance and integration, describe providing emotional support, suggest facilitating insight, and encourage offering paths to sustain personal enrichment addressing the challenges of gender bias. ${ }^{18}$ Lastly, the guidelines encourage participation in networking, facilitating nominations of qualified females for honors and awards, and encouraging collaboration in scholarly activities. ${ }^{18}$ Many of these are aspects are also potential benefits of mentorship for athletic trainers. ${ }^{1,2,16,18,23}$ The athletic training profession, specifically the National Athletic Trainers' Association could adapt the emergency medicine program for female athletic trainers and include: addressing challenges of gender bias, encouragement, participation in networking, facilitating nominations of qualified females for honors and awards, and encouraging collaboration in scholarly activities. Females should be encouraged to seek out mentorship and also receive guidance on how to do so.

Another attempt to integrate females into leadership is the American Council on Education, which has worked to increase and influence female equity, diversity, and development in higher education leadership. ${ }^{18}$ The American Council on Education focuses on programs for female leaders set on the principles of identity development, encouraging, assisting, linking, and supporting. The Inclusive Excellence Group, which is a group within the American Council on Education, hosts regional and national development 
programs for mid and senior-level female administrators who have aspirations to advance into higher leadership. ${ }^{18}$ This gives females an area to advance their leadership skills and increase their network. They have shown importance in increasing the national awareness of the significance of gender equality in higher education. ${ }^{18}$

\section{Limitations}

Though our study yielded valuable insights about females and mentorship within athletic training, there were some limitations due to the qualitative nature of the research. Individuals did volunteer to be interviewed for our research, so there may be bias in selfselection. For example, individuals who had more or less promising experiences with mentorship could have been more likely to volunteer to be interviewed, leading to potentially skewed results.

Another common limitation with qualitative research is the possibility of interviewer bias, which may have been present in this study. Bias is inherent in qualitative research, and we attempted to control for interviewer bias by completing external reviews of the interview script and the data to confirm our conclusions. To account for potential internal bias of the researchers, the team engaged in sharing their potential biases at the onset of the project and throughout the analysis process, engaging in opportunities to review our reflexivity.

\section{CONCLUSION}

Female athletic trainers are faced with challenges and barriers throughout their careers. These challenges can be minimized greatly with the guidance and support of quality mentors. Female athletic trainers struggle to find adequate female mentors to help them overcome specific gender challenges faced in this field. With the lack of adequate female mentors to provide guidance and even model behavior, females struggle to overcome gender-specific barriers and ultimately remove themselves from the clinical setting or the profession as a whole. We need to encourage and teach female athletic trainers how to overcome and mitigate genderspecific challenges to elongate female careers. The lengthening of their careers will increase the pool of adequate mentors that other females can benefit from down the line. The more females the profession has guiding and emulating success in the profession, the greater the likelihood of career retention and professional advancement.

\section{REFERENCES:}

1. Nottingham S, Barrett JL, Mazerolle SM, Eason CM. Examining the role mentorship plays in the development of athletic training preceptors. Athletic Training Education Journal. 2016;11(3):127-137.

2. Mazerolle SM, Borland JF, Burton LJ. The professional socialization of collegiate female athletic trainers: navigating experiences of gender bias. Journal of Athletic Training. 2012;47(6):694-703.

3. Thrasher AB, Walker SE, Hankemeier DA, Mulvihill T. Graduate-assistant athletic trainers' perceptions of professional socialization in the collegiate setting: part I. Journal of athletic training. 2016;51(10):758-770.

4. Mazerolle SM, Gavin KE, Pitney WA, Casa DJ, Burton L. Undergraduate athletic training students' influences on career decisions after graduation. J Athl Train. 2012;47(6):679-693.

5. Kirby JL, Walker SE, Mazerolle SM. Transition to practice for graduate assistant athletic trainers providing medical care in the secondary school setting. Journal of athletic training. 2018;53(5):521-528.

6. Kahanov L, Loebsack AR, Masucci MA, Roberts J. Perspectives on parenthood and working of female athletic trainers in the secondary school and collegiate settings. Journal of athletic training. 2010;45(5):459-466.

7. Simmons M. Gender Equality in the Athletic Training Profession. In:2019.

8. Mazerolle SM, Eason CM. Barriers to the role of the head athletic trainer for women in National Collegiate Athletic Association Division II and III settings. Journal of Athletic Training. 2016;51(7):557-565.

9. $\quad$ findings ss. 2018 salary survey findings. 2018.

10. Lewis C, Jin Y, Day C. Distribution of men and women among NCAA head team physicians, head athletic trainers, and assistant athletic trainers. JAMA internal medicine. 2020;180(2):324-326.

11. Mazerolle SM, Burton L, Cotrufo RJ. The experiences of female athletic trainers in the role of the head athletic trainer. Journal of athletic training. 2015;50(1):71-81.

12. Hill CE, Knox S, Thompson BJ, Williams EN, Hess SA, Ladany N. Consensual qualitative research: An update. Journal of counseling psychology. 2005;52(2):196.

13. Goodson L, Vassar M. An overview of ethnography in healthcare and medical education research. Journal of educational evaluation for health professions. 2011;8.

14. Pope C. Conducting ethnography in medical settings. Medical education. 2005;39(12):1180-1187. 
15. Kahanov L, Eberman LE. Age, sex, and setting factors and labor force in athletic training. In: National Athletic Trainers' Association, Inc; 2011.

16. Cross M, Lee S, Bridgman H, Thapa DK, Cleary M, Kornhaber R. Benefits, barriers and enablers of mentoring female health academics: An integrative review. PloS one. 2019;14(4):e0215319.

17. Dutta R, Hawkes SL, Kuipers E, Guest D, Fear NT, Iversen AC. One year outcomes of a mentoring scheme for female academics: a pilot study at the Institute of Psychiatry, King's College London. BMC Medical Education. 2011;11(1):1-9.

18. Pitney WA, Ehlers GG. A grounded theory study of the mentoring process involved with undergraduate athletic training students. Journal of Athletic Training. 2004;39(4):344.

19. Thrasher AB, Walker SE, Hankemeier DA, Mulvihill T. Graduate-assistant athletic trainers' perceptions of the supervisor's role in professional socialization: part II. Journal of athletic training. 2016;51(10):771-779.

20. Walker SE, Thrasher AB, Mazerolle SM. Exploring the perceptions of newly credentialed athletic trainers as they transition to practice. Journal of Athletic Training. 2016;51(8):601-612.

21. Spiva L, Hart PL, Pruner L, et al. Hearing the Voices of Newly Licensed RNs The Transition to Practice. AJN The American Journal of Nursing. 2013;113(11):24-32.

22. Hackett N. First Female Season-Long Athletic Training Intern for the Bengals. Cedarville News2019.

23. Hyre T, Chen S, Larson M. Perceptions concerning obstacles, stereotypes and discrimination faced by female sports reporters and other female sports professionals. Athens Journal of Sports. 2017;4(3):213-230.

24. Xie B, Zhou W, Xia D, Guo Y. What drives the trickle-down effect of calling orientation from supervisors to subordinates? The perspective of social learning theory. Frontiers in psychology. 2019;10:905.

25. Yehia BR, Cronholm PF, Wilson N, et al. Mentorship and pursuit of academic medicine careers: a mixed methods study of residents from diverse backgrounds. BMC medical education. 2014;14(1):1-8.

26. Siple BJ, Hopson RK, Sobehart HC, Turocy PS. Who should mentor me? Giving a voice to black women athletic training students. Athletic Training Education Journal. 2015;10(2):146-158.

27. Mazerolle SM, Pitney WA, Goodman A, et al. National Athletic Trainers' Association position statement: facilitating work-life balance in athletic training practice settings. Journal of athletic training. 2018;53(8):796-811.

28. Barrett JL, Mazerolle SM, Eason CM. Exploring senior level athletic training students' perceptions on burnout and work-life balance. Athletic Training Education Journal. 2016;11(2):110-118.

29. Mazerolle SM, Barrett JL. Work-life balance in higher education for women: perspectives of athletic training faculty. Athletic Training Education Journal. 2018;13(3):248-258.

30. Eason CM, Mazerolle SM, Goodman A. Motherhood and work-life balance in the National Collegiate Athletic Association Division I setting: Mentors and the female athletic trainer. Journal of athletic training. 2014;49(4):532-539.

31. Block BA, Tietjen-Smith T. The case for women mentoring women. Quest. 2016;68(3):306-315.

32. González-Pérez S, Mateos de Cabo R, Sáinz M. Girls in STEM: Is It a Female Role-Model Thing? Frontiers in Psychology. 2020;11:2204.

33. Kreuzer BK. Women and leadership: The effect of gender, gender-role orientation, socioeconomic status, and parental influence on women's aspirations to leader roles. 1992. 